\title{
Silicon Particles/Black Paint Coating for Performance Enhancement of Solar Absorbers
}

\author{
Shwe Sin Han ${ }^{1}$, Usman Ghafoor ${ }^{2, *}++_{\mathbb{D}}$, Tareq Saeed ${ }^{3,+}$, Hassan Elahi ${ }^{4,+}{ }^{\mathbb{D}}$, Usman Masud ${ }^{5,6}$, Laveet Kumar ${ }^{1}$, \\ Jeyraj Selvaraj ${ }^{1}$ and Muhammad Shakeel Ahmad ${ }^{1, * \mathbb{D}}$
}

1 Higher Institution Centre of Excellence (HICoE), UM Power Energy Dedicated Advanced Centre (UMPEDAC), Level 4, Wisma R \& D, University of Malaya, Jalan Pantai Baharu, Kuala Lumpur 59990 , Malaysia; shwesinhan2018@gmail.com (S.S.H.); laveet.kumar@gmail.com (L.K.); jeyraj@um.edu.my (J.S.)

2 Department of Mechanical Engineering, Institute of Space Technology, Islamabad 44000, Pakistan

3 Nonlinear Analysis and Applied Mathematics (NAAM)-Research Group, Department of Mathematics, Faculty of Science, King Abdulaziz University, P.O. Box 80203, Jeddah 21589, Saudi Arabia; tsalmalki@kau.edu.sa

4 Department of Mechanical and Aerospace Engineering, Sapienza University of Rome, 00185 Rome, Italy; hassan.elahi@uniroma1.it

5 Faculty of Electrical and Electronics Engineering, University of Engineering and Technology, Taxila 47050, Pakistan; usmanmasud123@hotmail.com

6 Department of Electrical Communication Engineering, University of Kassel, 34127 Kassel, Germany

* Correspondence: usmanghafoor99@gmail.com (U.G.); shakeelalpha@gmail.com (M.S.A.)

+ These authors have equally contributed as the second author in the manuscript.

Citation: Han, S.S.; Ghafoor, U.; Saeed, T.; Elahi, H.; Masud, U.; Kumar, L.; Selvaraj, J.; Ahmad, M.S. Silicon Particles/Black Paint Coating for Performance Enhancement of Solar Absorbers. Energies 2021, 14, 7140. https://doi.org/10.3390/ en14217140

Academic Editor: Dibin Zhu

Received: 29 July 2021

Accepted: 15 September 2021

Published: 1 November 2021

Publisher's Note: MDPI stays neutral with regard to jurisdictional claims in published maps and institutional affiliations.

Copyright: (C) 2021 by the authors. Licensee MDPI, Basel, Switzerland. This article is an open access article distributed under the terms and conditions of the Creative Commons Attribution (CC BY) license (https:// creativecommons.org/licenses/by/ $4.0 /$ )
Abstract: The availability of fresh drinkable water and water security is becoming a global challenge for sustainable development. In this regard, solar stills, due to their ease in operation, installation, and utilization of direct sunlight (as thermal energy), promise a better and sustainable future technology for water security in urban and remote areas. The major issue is its low distillate productivity, which limits its widespread commercialization. In this study, the effect of silicon (Si) particles is examined to improve the absorber surface temperature of the solar still absorber plate, which is the major component for increased distillate yield. Various weight percentages of Si particles were introduced in paint and coated on the aluminum absorber surface. Extensive indoor (using a selfmade halogen light-based solar simulator) and outdoor testing were conducted to optimize the concentration. The coatings with $15 \mathrm{wt} \% \mathrm{Si}$ in the paint exhibited the highest increase in temperature, namely, $98.5^{\circ} \mathrm{C}$ under indoor controlled conditions at $1000 \mathrm{~W} / \mathrm{m}^{2}$ irradiation, which is $65.81 \%$ higher than a bare aluminum plate and $37.09 \%$ higher compared to a black paint-coated aluminum plate. On the other hand, coatings with $10 \mathrm{wt} \% \mathrm{Si}$ reached up to $73.2{ }^{\circ} \mathrm{C}$ under uncontrolled outdoor conditions compared to $68.8^{\circ} \mathrm{C}$ for the black paint-coated aluminum plate. A further increase in concentration did not improve the surface temperature, which was due to an excessive increase in thermal conductivity and high convective heat losses.

Keywords: water; solar still; absorber; silicon; temperature

\section{Introduction}

Freshwater plays a crucial role in a sustainable environment. Therefore, the demand for drinkable water is increasing gradually every year due to population enlargement. Although $70 \%$ of the earth is covered with water, most of the accessible water cannot be utilized for drinking due to salinity and water contamination [1,2]. One of the potential alternatives to produce fresh water and decrease the cost of distillation plants is the utilization of solar energy directly. Various applications of solar energy use have been put forwarded, such as solar photovoltaics [3,4]. Solar distillation is one of the techniques to produce fresh water at a lower cost than the other possible seawater desalination processes $[5,6]$. The lower cost of manufacturing and installation is due to its simple design, 
use of less expensive and readily available raw material and tooling, and no moving components. More specifically, the solar distillation technique by using solar stills is the most feasible and environmentally friendly way to supply fresh water in arid and remote regions due to its ability to use thermal energy from the sun, little maintenance, simple design, little to no use of replacement components, and lower cost $[7,8]$.

A solar still consists of a basin to contain water and a glass top cover that allows the water to be exposed directly to sunlight to stimulate the evaporation process, where the distillate is collected from the bottom side of the glass cover. A schematic illustration of a solar still is shown in Figure 1. It is worth mentioning here that the solar absorber in a conventional solar still consists of a metal (generally copper or aluminum) sheet coated with black paint to improve sunlight absorption. The production efficiency of a solar still is much lower compared to other desalination techniques. The freshwater production efficiency directly relates to the absorber plate temperature and temperature difference between the absorber plate and backside of the glass cover, which creates a temperature difference and improve the evaporation rate [9]. Therefore, various studies have been conducted to increase the productivity of solar stills.

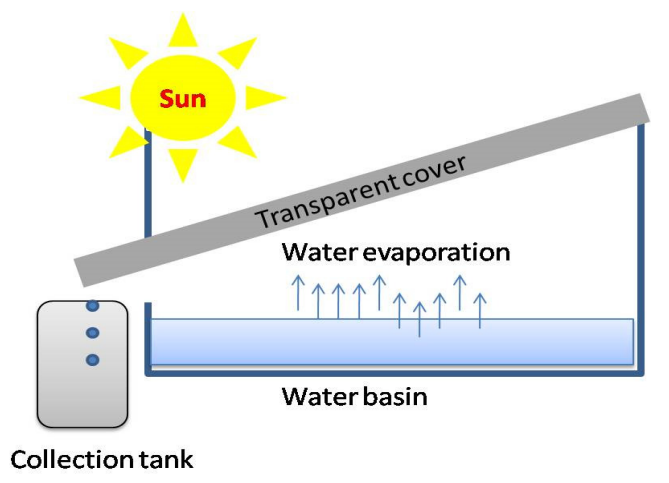

Figure 1. Schematic illustration of a solar still.

The solar still works on the evaporation and condensation principle: as the direct sunlight heats up the water and causes evaporation, the vapors condenses when coming into contact with the relatively colder surface of the glass cover, subsequently trickling down to a collection tank [10]. The depth of the basin water is one of the important factors in the evaporation rate and performance of a solar still; moreover, the salinity in water reduces the evaporation rate. This is because of the fact that impurities in water increase the boiling point, which, in turn, reduces the overall efficiency of the evaporation rate and performance. An experimental study investigated the effect of basin water depth on the performance of a single-slope (SS) basin-type solar still. The effect of water depth, varying from $2 \mathrm{~cm}$ to $10 \mathrm{~cm}$, and the salinity of the water, which was 3000, 50,000, 10,000, 150,000 , and 20,000 ppm on yield, were tested. The study showed that the thermal efficiency decreases with an increase in depth and salinity of the basin water. The maximum efficiency was obtained at the minimum water depth $(2 \mathrm{~cm})$ in the basin, producing the maximum volume of distilled water [11]. Another experiment was carried out on the performance of a single-slope (SS) solar still and double-slope (DS) solar still by changing the depth of the basin water at $1 \mathrm{~cm}, 2.5 \mathrm{~cm}, 5 \mathrm{~cm}$, and $7.5 \mathrm{~cm}$. From the experimental results, it was concluded that a decrease in water depth resulted in an increase in yield, and that the performance of the DS solar still outweighed the SS solar still at a similar water depth [12]. Another experiment was conducted between a single-basin double-slope (SBDS) solar still and double-basin double-slope (DBDS) solar still, with the use of different depths varying from 1 to $5 \mathrm{~cm}$. It was observed that the DBDS insulated still had a $17.38 \%$ higher yield than the SBDS insulated still at a $1 \mathrm{~cm}$ depth of the basin water. The results prove that the DBDS solar still gave a higher performance than the SBDS solar still and the depth of the basin water has a considerable effect on the production rate of a solar still [13]. The study has experimentally analyzed the effect of water depth in a comparison of the performance 
of a pyramid solar still (PSS) and the single-slope solar still and concluded that a reduction in depth gives a higher productivity, and that the PSS has a higher performance than the SS solar still because of its greater condensation area [14].

One of the main components that contribute a lot to solar still production efficiency is the base plate, which acts as a solar radiation absorber and provides the required energy to water. Generally, aluminum or copper plates coated with black paints have been employed for maximum radiation absorption. In a recent study, $\mathrm{TiO}_{2}$ nanoparticles have been mixed with black paint and coated on the absorbed plate in an attempt to increase the radiation absorption. A $1.5{ }^{\circ} \mathrm{C}$ increase in water temperature has been reported for $\mathrm{TiO}_{2}$-modified black paint compared to bare black paint. This increase in temperature leads to a $6.1 \%$ increase in solar still distillate yield [12]. In another study, $\mathrm{ZnO}$ nano particulates have been investigated as reinforcement to the absorber plate. An absorber temperature of $70^{\circ} \mathrm{C}$ has been reported when coated with nano tubular-shaped $\mathrm{ZnO}$ particles/black paint compared to a $60-65{ }^{\circ} \mathrm{C}$ temperature of the reference sample [13]. Various other nanomaterials, namely, carbon nanotubes (CNTs), carbon black, and graphene, have been employed to achieve the maximum temperature [15]. Similarly, $\mathrm{CuO}$ with various wt $\%$ from $10-40 \%$ has also been considered as a nanomaterial and mixed into paint to improve the distillate production efficiency. It has been claimed that the addition of $\mathrm{CuO}$ improves the efficiency by $16 \%$ and $25 \%$ as compared to the conventional solar still at $10 \%$ and $40 \%$ concentrations, respectively [16]. Another experimental study investigated the fumed $\mathrm{SiO}_{2}$ nanoparticles in black paint at a varied concentration from $10-40 \%$ coated on the absorber plate of a stepped solar still for augmenting the freshwater yield. The average temperature of the water and absorber increased by $10.2-12.3 \%$ by adding the optimized concentration of nanoparticles of $20 \%$ with black paint. Results also concluded that the concentration increase from 10 to $40 \%$, with $10 \%$ increment leading to a $27.2,34.2,18.3$, and $18.4 \%$ increase in efficiency, respectively, compared to that of ordinary black paint [17]. Similarly, one of the research groups developed two similar solar stills with varying color of paints other than black. One still was painted white while the another was painted black for comparison. Results obtained with the white-painted solar still had a $6.8 \%$ improvement in efficiency compared to the ordinary black paint [18].

Furthermore, some studies suggested mixing various nanoparticles, i.e., $\mathrm{CuO}, \mathrm{Al}_{2} \mathrm{O}_{2}$, $\mathrm{TiO}_{2}$, etc., directly with water for simplicity of operation $[19,20]$. In one study, experimental comparisons were investigated between the solid nanoparticles of a $\mathrm{CuO}$ and $\mathrm{Al}_{2} \mathrm{O}_{3}$ nanofluid and concluded that the nanoparticles enhanced freshwater production by around $125.0 \%$ and $133.64 \%$, respectively [21]. However, this approach (nanofluids) may contaminate the water due to its direct contact with water [13]. In another study, zinc microparticles were used to improve the surface absorption temperature [10]. Various other approaches for improved distillate yield include the use of wick materials, such as cotton, wool, nylon, wood pulp paper, styrene sponge, coral fleece, etc., and shape modification of the absorbed plate to improve the contact surface area, and have been employed with promising results.

In this study, metallic submicron-sized silicon particles are studied to improve the absorption property of absorber plates for solar still applications. Various concentrations of silicon were mixed with black paint and applied to the aluminum plate. Indoor and outdoor testing was conducted using an improvised apparatus for concentration optimization.

\section{Experimental Investigation}

\subsection{Samples Preparation}

The test samples were prepared using a simple chemical mixing method. Black paint was considered as the base matrix to paint onto an aluminum plate and Si nanoparticles in the various fractions $0.5,1,3,5,7,10,15$, and $20 \mathrm{wt} \%$ were mixed in black paint. In brief, the nanoparticles were suspended in isopropyl alcohol $(5 \mathrm{~mL})$, sonicated for $1 \mathrm{~h}$, and stirred for $5 \mathrm{~h}$ for proper suspension. The suspension was mixed with black paint using a mechanical mixer for $2 \mathrm{~min}$ and the now-formed formulation was applied to the aluminum 
plate using a hand brush. The samples were dried at room temperature for $24 \mathrm{~h}$. The same procedure was repeated for each concentration. Figure 2 shows the prepared samples for testing.

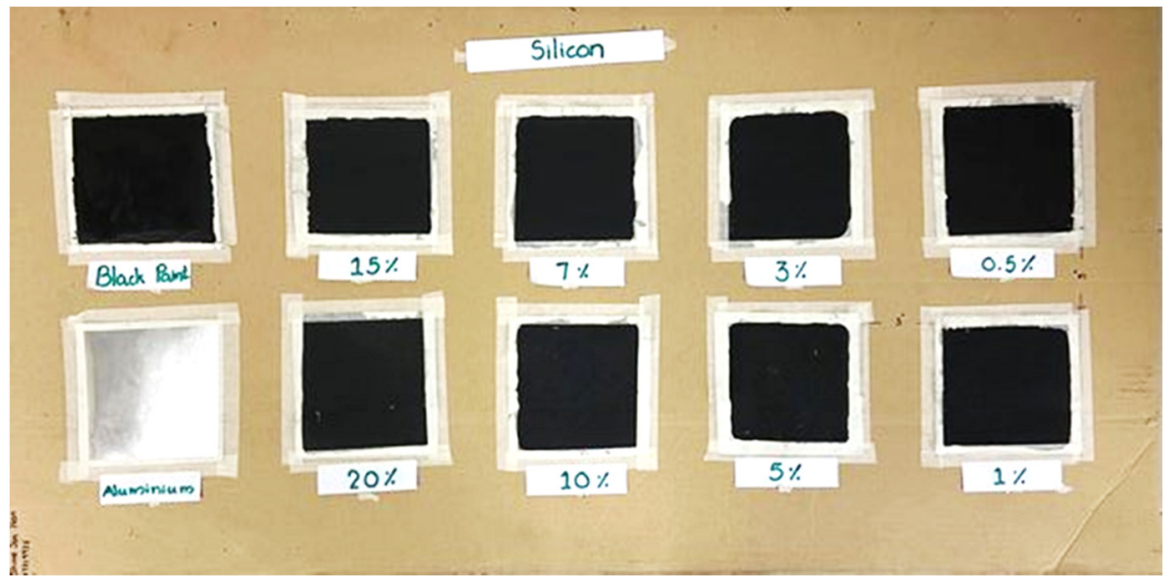

Figure 2. Samples under investigation.

\subsection{Indoor Setup and Experimental Procedure}

The indoor setup at the solar thermal laboratory, UMPEDAC, University of Malaya, was used. There were many components and instruments used in this experiment to fulfil the required indoor conditions. For providing the required irradiations, a solar simulator comprising 120 halogen bulbs (Brand: OSRAM, OSRAM GmbH Marcel-Breuer-Straße 680807 Munich, Germany) with power, voltage, and current capacity of $90 \mathrm{~W}, 12 \mathrm{~V}$, and $7.5 \mathrm{~A}$, respectively, was used. The solar simulator is controlled by three variable control AC-power-supply transformers, which can simulate the solar radiation from $100 \mathrm{~W} / \mathrm{m}^{2}$ to $1200 \mathrm{~W} / \mathrm{m}^{2}$. Further, a few other standard measuring instruments were used to record the data. Some key instrumentation and sensors used were a pyranometer (Brand: LI-COR, LI200R, LI-COR GmbH, Germany Siemensstraße 25A 61352 Bad Homburg Germany), data logger (Brand: Data taker (DT80), Thermo Fisher Scientific Australia Pty Ltd.), and thermocouples (K-type). The measuring and accuracy range of all the instruments and sensors are given in Table 1.

Table 1. Measurement ranges and accuracy of the instruments and sensors.

\begin{tabular}{ccc}
\hline Instrument & Measuring Range & Accuracy \\
\hline Pyranometer (Model: LI-COR, LI200R) & $0-2000 \mathrm{~W} / \mathrm{m}^{2}$ & $\pm 5 \%$ \\
Data Logger (Model: Data Taker DT80) & & $\pm 2 \%$ \\
Thermocouple (K-Type) & $-200-1000{ }^{\circ} \mathrm{C}$ & $\pm 1.50{ }^{\circ} \mathrm{C}$ \\
\hline
\end{tabular}

For the indoor experiment procedure, the samples of size $6 \times 6$ inches were placed on a cardboard in the solar simulator. The eight (08) samples with different concentrations of silicon (Si) nano particles-coated plates, one (01) black paint-coated plate, and one (01) bare aluminum plate were placed in two rows with a displacement of 3 inches apart on the cardboard. The K-type thermocouple was placed on each plate and a pyranometer in the center to record the change in temperature and varying radiations, respectively. Experiments were conducted in indoor working conditions with varying the radiation from $100 \mathrm{~W} / \mathrm{m}^{2}$ to $1000 \mathrm{~W} / \mathrm{m}^{2}$ using a solar simulator. It was observed that it took about $30 \mathrm{~min}$ in each irradiation level of the experiment to reach the stable conditions and then the solar simulator was switched off for about $15 \mathrm{~min}$ to record the decreasing temperature of all plates. The arrangement of the indoor experiment is systematically depicted in Figure 3. 


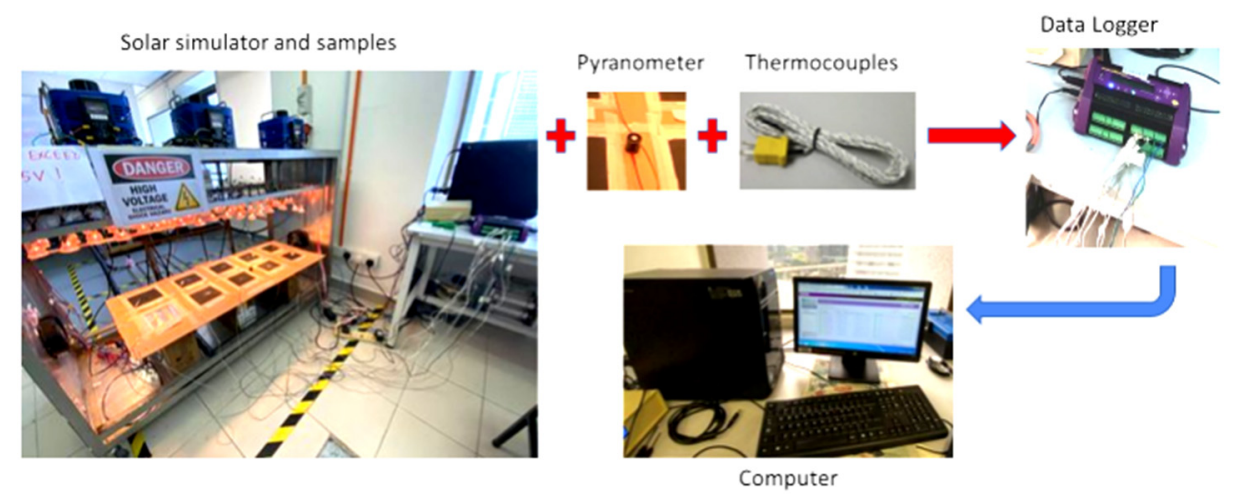

Figure 3. Indoor experimental setup.

\subsection{Outdoor Setup and Experimental Procedure}

The outdoor experimental setup was installed at the Solar Garden of Higher Institution Centre of Excellence, UM Power Energy Dedicated Advanced Centre (UMPEDAC), Kuala Lumpur, Malaysia. Experiments were carried out from 8.00 a.m. to 05:00 p.m. The same standard devices and instruments were used to record the data and the measuring and accuracy range of all the instruments and sensors has already been given in Table 1. Sensors were placed onto the systems at the necessary locations for recording the data. Other meteorological data, such as wind speed, etc., were measured using the weather station installed at the Solar Garden.

The same arrangement of samples, i.e., the silicon-coated nanoparticles, the plate coated with black paint, and the aluminum plate attached, were attached to a wooden sheet of a thickness of $1 \mathrm{~mm}$ and was mounted at an optimum inclined angle of 15 degrees. The layout of the outdoor experiment, including the position and connectivity of all the instruments and components, is systematically represented in Figure 4. The optimum angle was calculated using Cooper's Equation (1) to intercept the maximum radiation throughout the day [22]. Note that the experiment was performed for seven days from 8:00 a.m. to 5:00 p.m. and only the best data with the maximum sun hours are presented here.

$$
\delta=23.45 \sin \left[0.9863\left(284+n_{1}\right)\right]
$$

where $\delta$ is the inclination angle and $n_{1}$ is the day of the year.
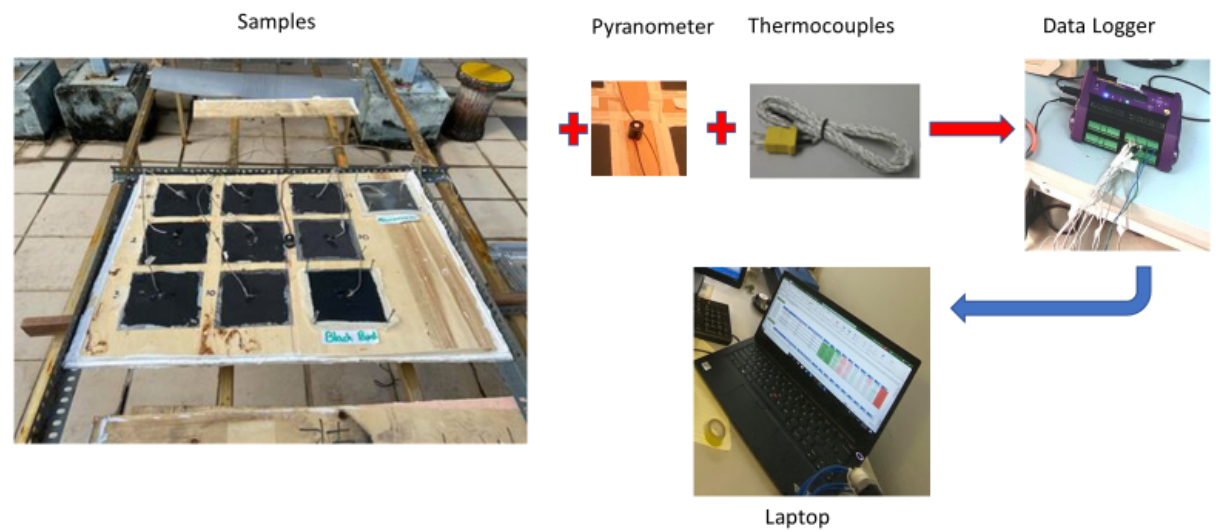

Figure 4. Setup of the outdoor experiment.

\section{Results and Discussion}

Figure 5a-c shows the scanning electron micrographs (SEM) of the as-received powder along with the X-ray diffraction (XRD) pattern and UV-vis spectra. The particles are of irregular shape with sizes ranging from micrometers to sub-micrometers; i.e., from $0.9-4 \mu \mathrm{m}$. The XRD pattern has been matched with the JCPDS\#27-1402 card [23]. The peaks 
mentioned concerning the 2-theta axis corresponds to the silicon element. Figure $5 \mathrm{c}$ shows the light absorption properties of the as-received powder, which is of prime importance to this study; a sharp absorption in UV; and a visible range of the solar spectrum was identified, for which the levels in the near-infrared region and again a small absorption in the far-infrared region were also noticed. The corresponding light transmission curve is also presented in Figure $5 \mathrm{c}$ to better understand the optical properties.
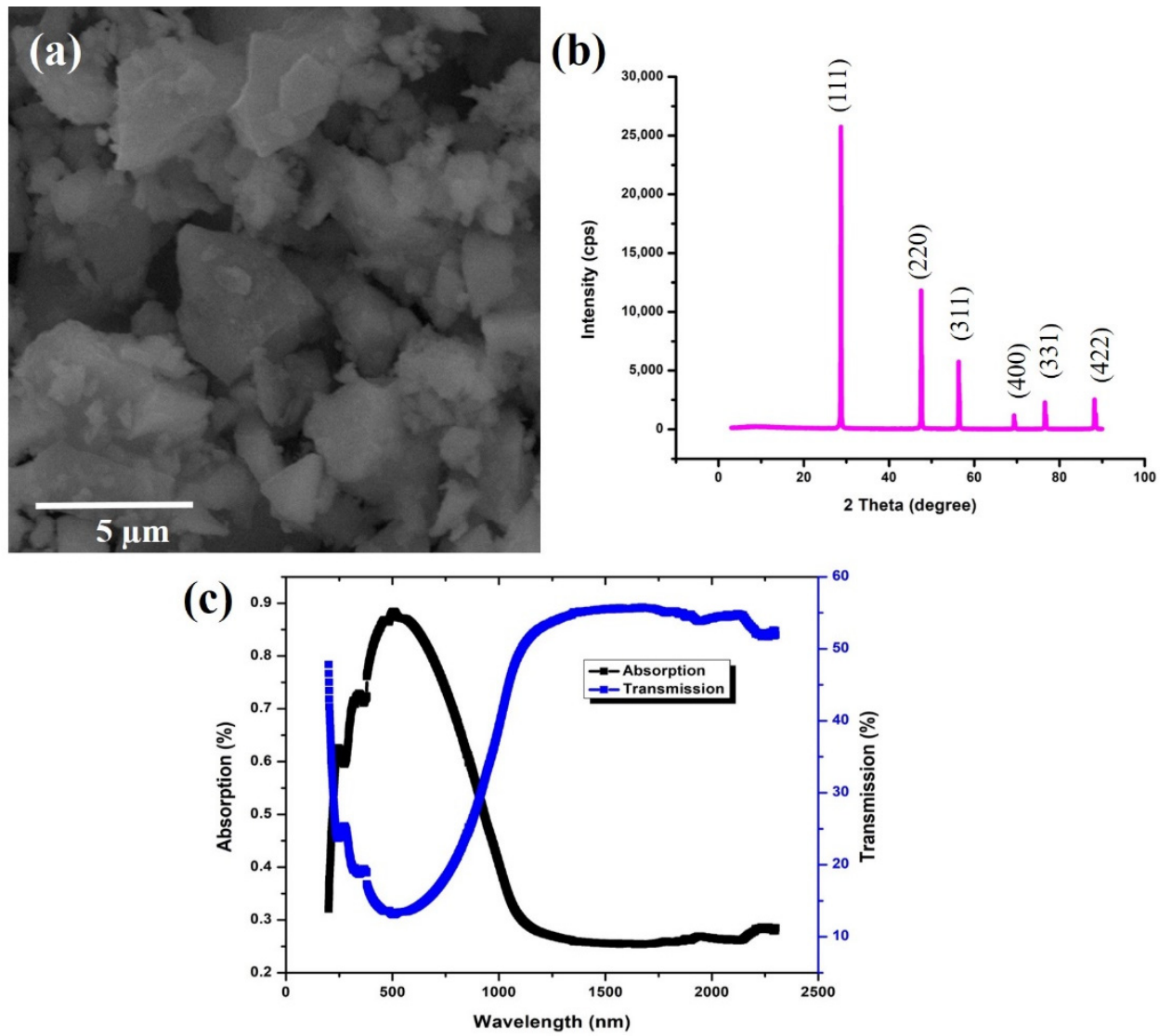

Figure 5. (a) SEM micrograph, (b) XRD pattern, and (c) UV-vis spectra of the as-received Si powder.

A notable outcome of the performance of the absorber plates is properly analyzed from the evidence and presented in detail with the results, followed by insightful discussion. In the following sections, the indoor and outdoor experiment results are presented, which demonstrate the complete statistical and graphical information about the beneficial effects of using various Silicon (Si) concentrations with black paint.

\subsection{Indoor Analysis}

In the present study, the indoor experiment was conducted by varying the irradiation from 100 to $1000 \mathrm{~W} / \mathrm{m}^{2}$; however, for the purpose of our analysis, the effect of temperature on the absorber plates under the increment of $200 \mathrm{~W} / \mathrm{m}^{2}$ and rate of drop in temperature is shown in Figure 6. The left-hand side of Figure 6 illustrates the rise in temperature at $200,600,800$, and $1000 \mathrm{~W} / \mathrm{m}^{2}$, and the right-hand side illustrates the rate of a temperature drop on cooling. As illustrated in Figure $6 \mathrm{a}-\mathrm{d}$, the results showed a steady increase in surface temperature of the absorber plate with an increase in the concentration as well as solar irradiation. Furthermore, the cooling curves show an increase in the rate of cooling, as can be seen in Figure 6ai-di. This increased cooling rate corresponds to the increased thermal conductivity of specimens with an increasing concentration. The summary of the temperatures for various concentrations at maximum irradiation is presented in Table 2. 
(a)

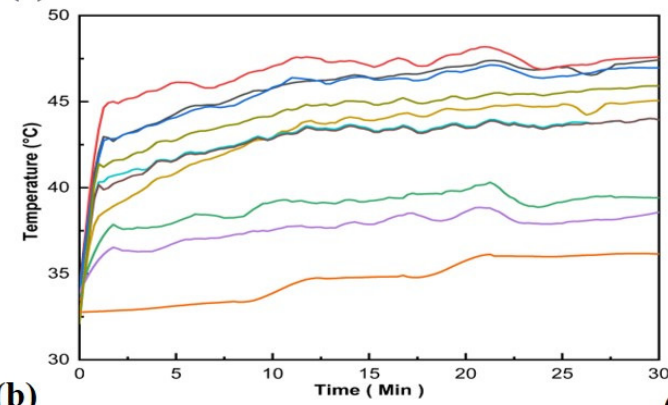

(b)

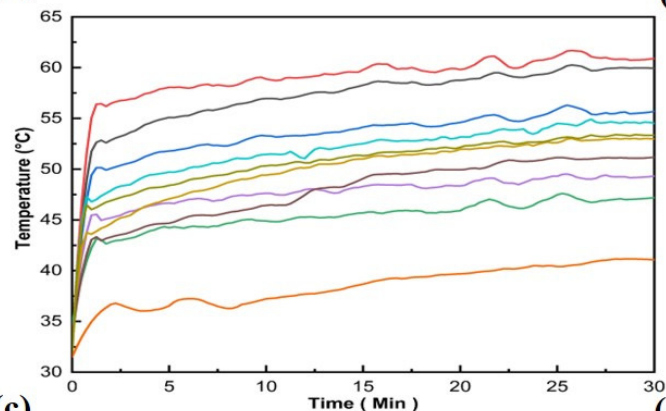

(c)

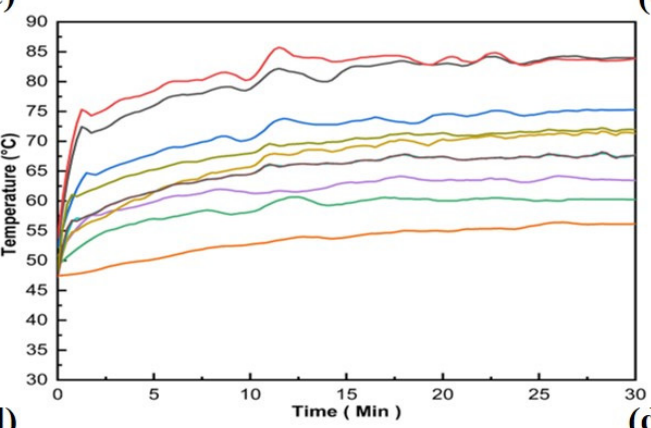

(ci)

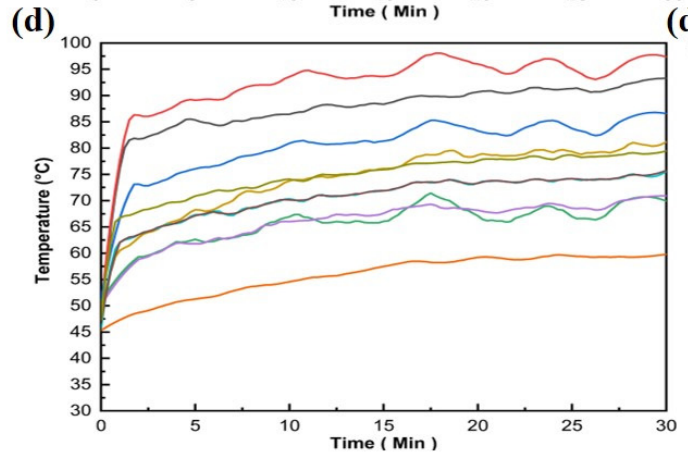

(di)

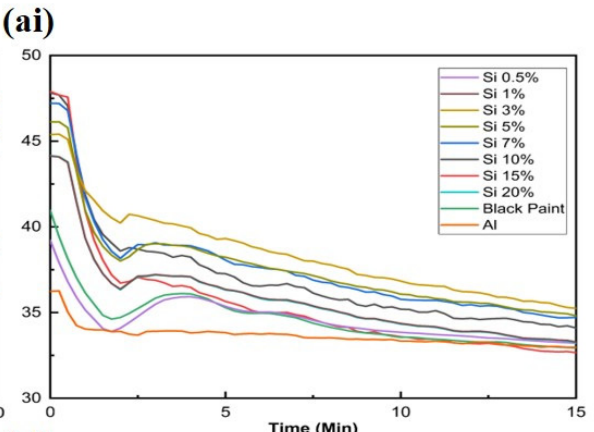

(bi)
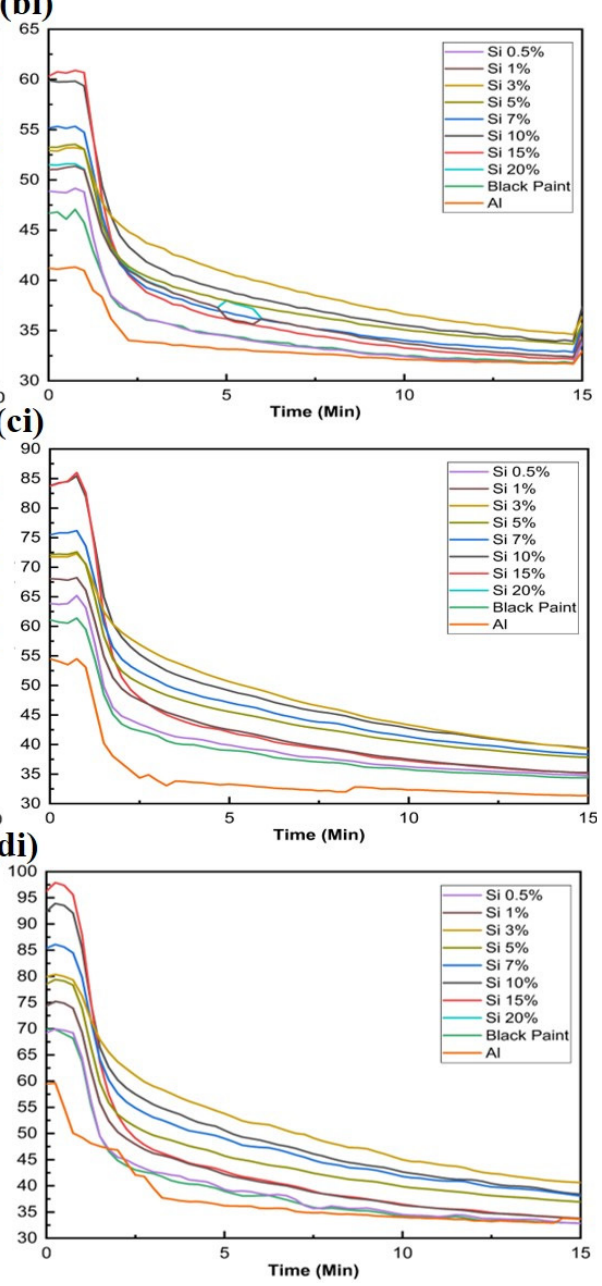

Figure 6. Effect on absorber temperature at an irradiation exposure of (a) $200 \mathrm{~W} / \mathrm{m}^{2}$, (b) $400 \mathrm{~W} / \mathrm{m}^{2}$, (c) $800 \mathrm{~W} / \mathrm{m}^{2}$, and (d) $1000 \mathrm{~W} / \mathrm{m}^{2}$, and the temperature-drop profile (ai-di). 
Table 2. Summary of the maximum observed temperature on the absorber surface vs. concentration in indoor conditions.

\begin{tabular}{cccc}
\hline Sr. No. & $\begin{array}{c}\text { Matrix (Coated on } \\
\text { Aluminum Sheet) }\end{array}$ & $\begin{array}{c}\text { Silicon Concentration } \\
(\mathbf{w t} \mathbf{\%})\end{array}$ & $\begin{array}{c}\text { Maximum Temperature at } \\
\mathbf{1 0 0 0} \mathbf{W} / \mathbf{m}^{\mathbf{2}}\end{array}$ \\
\hline 1 & Black paint & $0.5 \%$ & $72.8 \pm 2 \%$ \\
2 & Black paint & $1 \%$ & $75.7 \pm 2 \%$ \\
3 & Black paint & $3 \%$ & $79.4 \pm 2 \%$ \\
4 & Black paint & $5 \%$ & $81.8 \pm 3 \%$ \\
5 & Black paint & $7 \%$ & $87.8 \pm 2 \%$ \\
6 & Black paint & $10 \%$ & $93.4 \pm 3 \%$ \\
7 & Black paint & $15 \%$ & $98.5 \pm 2 \%$ \\
8 & Black paint & $20 \%$ & $79.3 \pm 2 \%$ \\
9 & Black paint & $0 \%$ & $71.9 \pm 2 \%$ \\
10 & Aluminum reference & & $59.4 \pm 2 \%$ \\
\hline
\end{tabular}

The maximum temperature measured for specimens containing $0.5 \mathrm{wt} \% \mathrm{Si}$ at $1000 \mathrm{~W} / \mathrm{m}^{2}$ irradiations was $72.8{ }^{\circ} \mathrm{C}$, which is $22.58 \%$ higher compared to bare aluminum plate and $1.39 \%$ higher compared to the black paint-coated aluminum plate. Specimens containing $1 \mathrm{wt} \%, 3 \mathrm{wt} \%, 5 \mathrm{wt} \%, 7 \mathrm{wt} \%$, and $10 \mathrm{wt} \%$ exhibited the maximum temperatures of approximately $75.6^{\circ} \mathrm{C}, 79.3{ }^{\circ} \mathrm{C}, 81.7{ }^{\circ} \mathrm{C}, 87.8{ }^{\circ} \mathrm{C}$, and $93.4{ }^{\circ} \mathrm{C}$, respectively. The highest temperature was attained in the case of specimens containing $15 \mathrm{wt} \% \mathrm{Si}$ at a $1000 \mathrm{~W} / \mathrm{m}^{2}$ irradiation level was $98.5^{\circ} \mathrm{C}$, which is $65.81 \%$ higher compared to the bare aluminum plate and $37.15 \%$ higher compared to the black paint-coated aluminum plate. A further increase in Si concentration in the black paint did not increase the surface temperature. For example, specimens containing $20 \mathrm{wt} \% \mathrm{Si}$ in black paint exhibited $79.3^{\circ} \mathrm{C}$. This reduction in surface temperature is due to an excessive increase in thermal conductivity (cooling rate, Figure 6ai-di), which leads to an increase in thermal convective losses in the surrounding environment.

\subsection{Outdoor Analysis}

The weather of Kuala Lumpur experiences an equatorial climate illustrated by hot and humid weather throughout the whole year [24]. The Southwest monsoon takes place from April to September and the Northeast Monsoon occurs from October to March. The Southwest monsoon highlights a drier climate with less precipitation contrasted with the Northeast monsoon that brings more rainfall [25]. The outdoor experiments were conducted from 8:00 a.m. to 5:00 p.m. for about 7 days in September. The data for the best day are presented in Figure 7. It was noted that the tropical thunderstorms and rainfalls occurred usually in the afternoon although the weather conditions were generally good in the morning during the experiments. As shown in Figure 7a, it is observed that the solar intensity was lower in the morning and gradually increased, reaching its maximum at around noon and declined significantly because of cloudy weather conditions at this time. Then, it increased sharply and fluctuated before reaching the peak point at 1 p.m. and fell during the evening hours. It is also found that the wind speed steadily rose during the morning and hit to the maximum $7 \mathrm{~m} / \mathrm{s}$ around $3: 30 \mathrm{p} . \mathrm{m}$. and was considerably reduced in the evening. 
(a)

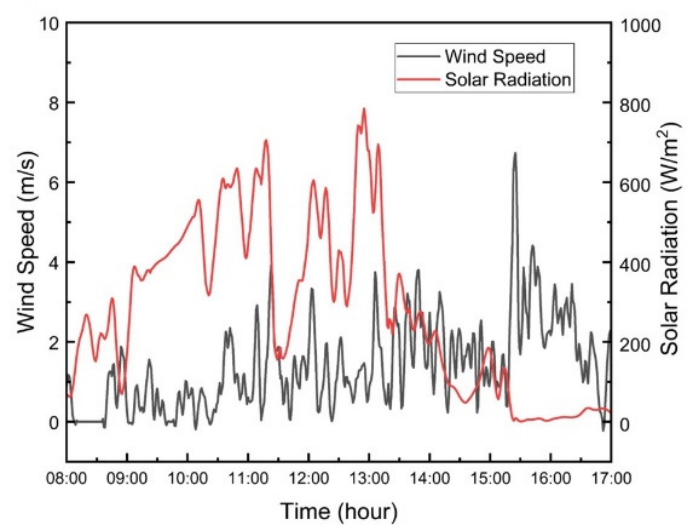

(b)

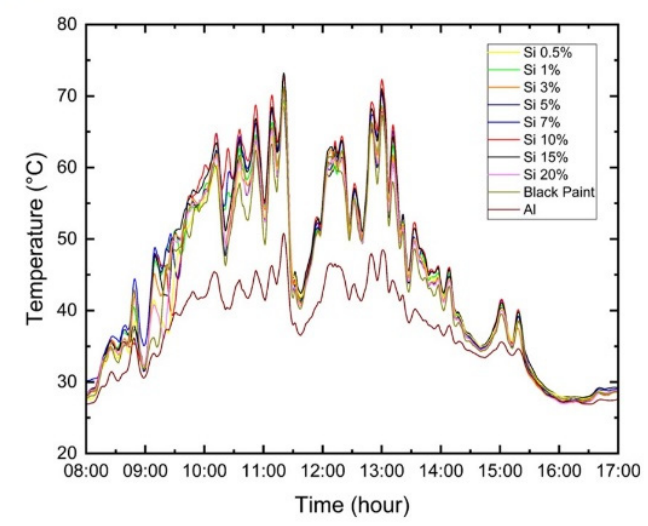

Figure 7. Outdoor experiment data at 27 September 2020: (a) weather profile, and (b) temperature of the absorber plates.

The outdoor temperature variations of the plates with silicon particles at different concentrations are demonstrated in Figure $7 \mathrm{~b}$, whereas the summary of the temperature is provided in Table 3. Outdoor results followed almost the same trend as indoor for the specimens containing $0.5 \mathrm{wt} \% \mathrm{Si}, 1 \mathrm{wt} \% \mathrm{Si}, 3 \mathrm{wt} \% \mathrm{Si}, 5 \mathrm{wt} \% \mathrm{Si}$, and $7 \mathrm{wt} \% \mathrm{Si}$, exhibiting $68.8^{\circ} \mathrm{C}, 69.4^{\circ} \mathrm{C}, 70.4{ }^{\circ} \mathrm{C}, 70.8^{\circ} \mathrm{C}$, and $71.3^{\circ} \mathrm{C}$, respectively. Further, in outdoor conditions, specimens containing $10 \mathrm{wt} \% \mathrm{Si}$ exhibited the maximum surface temperature of $73.2^{\circ} \mathrm{C}$, outperforming the specimen containing $15 \mathrm{wt} \% \mathrm{Si}$, which exhibited the highest temperature in indoor conditions. This behavior can be correlated with the cooling curves presented in Figure 6ai-di. With the increase in concentration, the thermal conductivity increased, which caused specimens to cool faster, giving heat energy to the surroundings at a faster rate. The cooling curve of the specimens containing $15 \mathrm{wt} \% \mathrm{Si}$ shows a higher cooling rate compared to specimens containing $10 \mathrm{wt} \% \mathrm{Si}$. As the outdoor conditions are fluctuating from $200 \mathrm{~W} / \mathrm{m}^{2}$ to $800 \mathrm{~W} / \mathrm{m}^{2}$ on that particular day, the specimens with higher cooling rates lose heat energy as the convective loss at a faster rate compared to specimens having a less to optimum cooling rate. Further, an increase in concentration to $20 \mathrm{wt} \%$ exhibited $70.2^{\circ} \mathrm{C}$, which is in line with the indoor trend.

Table 3. Summary of the maximum observed temperature on the absorber surface vs. the concentration of silicon in black paint.

\begin{tabular}{cccccc}
\hline Sr. No. & $\begin{array}{c}\text { Matrix } \\
\text { (Coated on } \\
\text { Aluminum } \\
\text { Sheet) }\end{array}$ & $\begin{array}{c}\text { Silicon } \\
\text { Concentration } \\
(\mathbf{w t} \%)\end{array}$ & $\begin{array}{c}\text { Maximum } \\
\text { Temperature } \\
\left({ }^{\circ} \mathbf{C}\right)\end{array}$ & $\begin{array}{c}\text { Average } \\
\text { Temperature } \\
\left({ }^{\circ} \mathbf{C}\right)\end{array}$ & $\begin{array}{c}\text { Measuring } \\
\text { Accuracy } \\
\left({ }^{\circ} \mathbf{C}\right)\end{array}$ \\
\hline 1 & Black paint & $0.5 \%$ & 68.9 & 44.0 & \pm 1.5 \\
2 & Black paint & $1 \%$ & 69.4 & 44.0 & \pm 1.5 \\
3 & Black paint & $3 \%$ & 70.5 & 44.5 & \pm 1.5 \\
4 & Black paint & $5 \%$ & 70.9 & 44.8 & \pm 1.5 \\
5 & Black paint & $7 \%$ & 71.3 & 45.6 & \pm 1.5 \\
6 & Black paint & $10 \%$ & 73.2 & 45.6 & \pm 1.5 \\
7 & Black paint & $15 \%$ & 72.7 & 45.6 & \pm 1.5 \\
8 & Black paint & $20 \%$ & 70.3 & 44.3 & \pm 1.5 \\
9 & Black paint & $0 \%$ & 68.8 & 43.4 & \pm 1.5 \\
10 & Aluminum & & 50.8 & 36.9 & \pm 1.5 \\
\hline
\end{tabular}

In terms of average temperature throughout the particular day, the average temperature did not change much, and the temperature increase is within the accuracy range of thermocouples for specimens with only black paint and with varying concentrations. The maximum average temperature was exhibited by the specimen containing $10 \mathrm{wt} \% \mathrm{Si}$; i.e., 
$45.6^{\circ} \mathrm{C}$, which is $23.8 \%$ higher compared to the bare aluminum plate and $5.13 \%$ higher compared to only black paint-coated aluminum plate.

\section{Conclusions}

The technology of solar stills is improving at a great pace to avoid future scarcity of fresh drinking water. In this study, silicon particles were investigated in an attempt to increase the sunlight absorption of the solar still absorber plate. Various concentrations of silicon particles were mixed with black paint and applied to the absorber plate. SEM and XRD were employed to examine the surface morphology and composition, respectively. UV-Vis spectroscopy was conducted to study the optical absorption properties of silicon. Indoor and outdoor tests were conducted using an improvised apparatus. With the introduction of Si particles into black paint, a temperature rise was observed, which can be associated with the ability of silicon to absorb sunlight in UV and the visible range of the solar spectrum. The highest temperature of $98.5^{\circ} \mathrm{C}$ was recorded for samples containing $15 \mathrm{wt} \% \mathrm{Si}$ in indoor conditions at $1000 \mathrm{w} / \mathrm{m}^{2}$ irradiation levels. In turn, the specimen with $10 \mathrm{wt} \%$ Si performed the best in outdoor conditions, achieving a maximum of $73.2{ }^{\circ} \mathrm{C}$ and $45.6^{\circ} \mathrm{C}$ average temperature. This difference between the indoor and outdoor conditions is due to the varying thermal conductions of the specimens due to the concentration of $\mathrm{Si}$ particles. A further increment in concentration did not effectively improve the absorption characteristics due to excessive convective heat losses.

Author Contributions: Conceptualization, M.S.A. and H.E.; formal analysis, S.S.H. and L.K.; funding acquisition, U.G.; investigation, U.M. and T.S.; methodology, L.K. and J.S.; project administration, J.S.; resources, T.S.; validation, U.M. and H.E; writing—original draft, S.S.H. and M.S.A.; writingreview and editing, T.S. and U.G. All authors have read and agreed to the published version of the manuscript.

Funding: (1) This research and APC charges were funded by Japan International Cooperation Agency for AUN/SEED-Net on Collaboration Education Program UM CEP 1901, Japan ASEAN Collaborative Education Program (JACEP). (2) This research was partially funded by UM Power Energy Dedicated Advanced Centre (UMPEDAC) and the Higher Institution Centre of Excellence (HICoE) Program Research Grant, UMPEDAC_-2020 (MOHE HICOE-UMPEDAC), Ministry of Education Malaysia, TOP100 UMPEDAC, RU003-2020, University of Malaya.

Informed Consent Statement: Not applicable.

Data Availability Statement: The prepared samples to support the findings of this study are available from the corresponding authors upon reasonable request.

Acknowledgments: The authors would like to acknowledge the Japan International Cooperation Agency for AUN/SEED-Net on Collaboration Education Program UM CEP 1901, Japan ASEAN Collaborative Education Program (JACEP). The authors thank the technical and financial assistance of UM Power Energy Dedicated Advanced Centre (UMPEDAC) and the Higher Institution Centre of Excellence (HICoE) Program Research Grant, UMPEDAC—2020 (MOHE HICOE-UMPEDAC), Ministry of Education Malaysia, TOP100 UMPEDAC, RU003-2020, University of Malaya.

Conflicts of Interest: The authors declare no conflict of interest.

\section{References}

1. Biswas, A.K.; Tortajada, C. Water Crisis and Water Wars: Myths and Realities; Taylor \& Francis: Abingdon, UK, 2019.

2. Llácer-Iglesias, R.M.; López-Jiménez, P.; Pérez-Sánchez, M. Energy Self-Sufficiency Aiming for Sustainable Wastewater Systems: Are All Options Being Explored? Sustainability 2021, 13, 5537. [CrossRef]

3. Fayaz, H.; Ahmad, M.S.; Pandey, A.K.; Abd Rahim, N.; Tyagi, V.V. A Novel Nanodiamond/Zinc Nanocomposite as Potential Counter Electrode for Flexible Dye Sensitized Solar Cell. Solar Energy 2020, 197, 1-5. [CrossRef]

4. Pandey, A.; Ahmad, M.S.; Alizadeh, M.; Rahim, N.A. Improved electron density through hetero-junction binary sensitized $\mathrm{TiO}_{2} / \mathrm{CdTe} / \mathrm{D} 719$ system as photoanode for dye sensitized solar cell. Phys. E Low-Dimens. Syst. Nanostruct. 2018, 101, 139-143. [CrossRef]

5. Liu, S.; Wang, Z.; Han, M.; Wang, G.; Hayat, T.; Chen, G. Energy-water nexus in seawater desalination project: A typical water production system in China. J. Clean. Prod. 2020, 279, 123412. [CrossRef] 
6. Besha, A.T.; Tsehaye, M.T.; Tiruye, G.A.; Gebreyohannes, A.Y.; Awoke, A.; Tufa, R.A. Deployable Membrane-Based Energy Technologies: The Ethiopian Prospect. Sustainability 2020, 12, 8792. [CrossRef]

7. Liu, F.; Wang, L.; Bradley, R.; Zhao, B.; Wu, W. Highly efficient solar seawater desalination with environmentally friendly hierarchical porous carbons derived from halogen-containing polymers. RSC Adv. 2019, 9, 29414-29423. [CrossRef]

8. Alawi, O.; Kamar, H.; Mallah, A.; Mohammed, H.; Sabrudin, M.; Newaz, K.; Najafi, G.; Yaseen, Z. Experimental and Theoretical Analysis of Energy Efficiency in a Flat Plate Solar Collector Using Monolayer Graphene Nanofluids. Sustainability 2021, $13,5416$. [CrossRef]

9. Abujazar, M.S.S.; Fatihah, S.; Kabeel, A. Seawater desalination using inclined stepped solar still with copper trays in a wet tropical climate. Desalination 2017, 423, 141-148. [CrossRef]

10. Ahmad, M.; Han, S.; Zafar, A.; Ghafoor, U.; Rahim, N.; Ali, M.; Rim, Y. Indoor and Outdoor Performance Study of Metallic Zinc Particles in Black Paint to Improve Solar Absorption for Solar Still Application. Coatings 2021, 11, 536. [CrossRef]

11. Srithar, K.; Rajaseenivasan, T. Recent fresh water augmentation techniques in solar still and HDH desalination-A review. Renew. Sustain. Energy Rev. 2018, 82, 629-644. [CrossRef]

12. Kabeel, A.; Sathyamurthy, R.; Sharshir, S.; Manokar, M.; Panchal, H.; Prakash, N.; Prasad, C.; Nandakumar, S.; El Kady, M. Effect of water depth on a novel absorber plate of pyramid solar still coated with $\mathrm{TiO}_{2}$ nano black paint. J. Clean. Prod. 2019, 213, 185-191. [CrossRef]

13. Saleh, S.M.; Soliman, A.M.; Sharaf, M.A.; Kale, V.; Gadgil, B. Influence of solvent in the synthesis of nano-structured ZnO by hydrothermal method and their application in solar-still. J. Environ. Chem. Eng. 2017, 5, 1219-1226. [CrossRef]

14. Abdelal, N.; Taamneh, Y. Enhancement of pyramid solar still productivity using absorber plates made of carbon fiber/CNTmodified epoxy composites. Desalination 2017, 419, 117-124. [CrossRef]

15. Baticados, E.J.N.; Capareda, S.C.; Liu, S.; Akbulut, M. Advanced Solar Still Development: Improving Distilled Water Recovery and Purity via Graphene-Enhanced Surface Modifiers. Front. Environ. Sci. 2020, 8, 531049. [CrossRef]

16. Kabeel, A.; Omara, Z.; Essa, F.; Abdullah, A.; Arunkumar, T.; Sathyamurthy, R. Augmentation of a solar still distillate yield via absorber plate coated with black nanoparticles. Alex. Eng. J. 2017, 56, 433-438. [CrossRef]

17. Sathyamurthy, R.; Kabeel, A.E.; Balasubramanian, M.; Devarajan, M.; Sharshir, S.W.; Manokar, M. Experimental study on enhancing the yield from stepped solar still coated using fumed silica nanoparticle in black paint. Mater. Lett. 2020, $272,127873$. [CrossRef]

18. Tenthani, C.; Madhlopa, A.; Kimambo, C.Z.M. Improved Solar Still for Water Purification. J. Sustain. Energy Environ. 2012, 3, 111-113.

19. Modi, K.V.; Jani, H.K.; Gamit, I.D. Impact of orientation and water depth on productivity of single-basin dual-slope solar still with $\mathrm{Al}_{2} \mathrm{O}_{3}$ and $\mathrm{CuO}$ nanoparticles. J. Therm. Anal. Calorim. 2021, 143, 899-913. [CrossRef]

20. Arunkumar, T.; Murugesan, D.; Raj, K.; Denkenberger, D.; Viswanathan, C.; Rufuss, D.D.W.; Velraj, R. Effect of nano-coated CuO absorbers with PVA sponges in solar water desalting system. Appl. Therm. Eng. 2019, 148, 1416-1424. [CrossRef]

21. Kabeel, A.; Omara, Z.; Essa, F. Improving the performance of solar still by using nanofluids and providing vacuum. Energy Convers. Manag. 2014, 86, 268-274. [CrossRef]

22. Yadav, A.K.; Chandel, S. Tilt angle optimization to maximize incident solar radiation: A review. Renew. Sustain. Energy Rev. 2013, 23, 503-513. [CrossRef]

23. Wang, M.-S.; Fan, L.-Z. Silicon/carbon nanocomposite pyrolyzed from phenolic resin as anode materials for lithium-ion batteries. J. Power Sources 2013, 244, 570-574. [CrossRef]

24. Meteoblue. Available online: https://www.meteoblue.com/en/weather/historyclimate/weatherarchive/kuala-lumpur_ malaysia_1735161?fcstlength $=1$ y\&year=2020\&month $=12$ (accessed on 22 December 2020).

25. Tang, K.H.D. Climate change in Malaysia: Trends, contributors, impacts, mitigation and adaptations. Sci. Total Environ. 2019, 650, 1858-1871. [CrossRef] 